\title{
Potential Use of Amla (Phyllanthus emblica L.) Fruit Extract to Protect Skin Keratinocytes from Inflammation and Apoptosis after UVB Irradiation
}

\author{
Khwandow Kunchana ${ }^{1}\left(\mathbb{D}\right.$, Wattanased Jarisarapurin ${ }^{1}{ }^{\circledR}$, Linda Chularojmontri ${ }^{2}$ \\ and Suvara K. Wattanapitayakul ${ }^{1, * \mathbb{D}}$ \\ 1 Department of Pharmacology, Faculty of Medicine, Srinakharinwirot University, Bangkok 10110, Thailand; \\ Khwandow.kun@g.swu.ac.th (K.K.); wattanased.jarisalapurin@g.swu.ac.th (W.J.) \\ 2 Department of Preclinical Sciences, Faculty of Medicine, Thammasat University, Khlong Luang, \\ Pathum Thani 12121, Thailand; clinda@staff.tu.ac.th \\ * Correspondence: suvara@g.swu.ac.th; Tel.: +66-2649-5385
}

\section{check for} updates

Citation: Kunchana, K.; Jarisarapurin, W.; Chularojmontri, L.; Wattanapitayakul, S.K. Potential Use of Amla (Phyllanthus emblica L.) Fruit Extract to Protect Skin Keratinocytes from Inflammation and Apoptosis after UVB Irradiation. Antioxidants 2021, 10, 703. https://doi.org/ 10.3390/antiox10050703

Academic Editor: Salvador Mañez Aliño

Received: 7 April 2021

Accepted: 27 April 2021

Published: 29 April 2021

Publisher's Note: MDPI stays neutral with regard to jurisdictional claims in published maps and institutional affiliations.

Copyright: (c) 2021 by the authors. Licensee MDPI, Basel, Switzerland. This article is an open access article distributed under the terms and conditions of the Creative Commons Attribution (CC BY) license (https:/ / creativecommons.org/licenses/by/ $4.0 /)$.

\begin{abstract}
Ultraviolet B (UVB) exposure is the primary risk factor for the deadliest type of skin cancer-melanoma. Incorporating natural antioxidants in skin protection products is currently a favored research theme. For this study, we selected Phyllanthus emblica L. fruit extract (PE) to assess its potential use in dermal protection against UVB-induced keratinocyte inflammation and apoptosis. High-performance liquid chromatography (HPLC) was used to investigate PE's phytochemical constituents (ascorbic acid, ellagic acid, gallic acid, chlorogenic acid, and quercetin), while ferric reducing antioxidant power (FRAP), oxygen radical absorbance capacity (ORAC), total ROS, $\mathrm{OH}^{\bullet}, \mathrm{O}_{2}{ }^{\bullet-}$, and $\mathrm{H}_{2} \mathrm{O}_{2}$-scavenging activities were used to determine the antioxidant properties. PE significantly increased the cell viability (MTT assay) and reduced apoptosis (Hoechst staining) in $\mathrm{HaCaT}$ cells exposed to UVB $\left(40 \mathrm{~mJ} / \mathrm{cm}^{2}\right)$. PE abolished oxidative stress by reducing the production of intracellular ROS, $\mathrm{O}_{2}{ }^{\bullet-}$ and $\mathrm{H}_{2} \mathrm{O}_{2}$ production. Catalase activity (but not superoxide dismutase or glutathione peroxidase activity) was enhanced in keratinocytes incubated with PE prior to UVB exposure. Western blot analysis suggested that PE inhibited cytochrome c release and inhibited the dysregulation of PI3K/Akt without any impact on p38 activation. PE attenuated the inflammatory response to UVB irradiation by inhibiting $A P-1, N F-\kappa B$, and the mediator $\mathrm{PGE}_{2}$. Thus, $\mathrm{PE}$ is a candidate with great potential for use as an active ingredient in skin care products.
\end{abstract}

Keywords: amla; Phyllanthus emblica; Emblica officinalis; keratinocytes; HaCaT; ultraviolet rays; UVB; oxidative stress; reactive oxygen species (ROS); antioxidants

\section{Introduction}

UV rays are a major cause of skin inflammation, which leads to irreversible cell damage, photoaging, and skin cancer [1]. The critical mediators associated with the mechanism of UV-induced cell damage are reactive oxygen species (ROS), which trigger the formation of inflammatory signaling cascades in skin cells, inducing the production of proinflammatory cytokines and apoptotic mediators [2]. Unlike the penetration of UVA $(320-400 \mathrm{~nm})$, that of UVB $(280-320 \mathrm{~nm})$ is limited to the epidermis layer due to the shorter wavelengths, resulting in skin burning, which is the prominent risk factor for the deadliest type of skin cancer-melanoma. To prevent the development of new cancer cells, reducing risk factors and improving protective factors are equally important [3].

UVB radiation can cause skin cancer by direct DNA attack, generating an excessive amount of ROS which, in turn, also cause DNA damage and lipid peroxidation as well as protein modifications and degradation [4]. These damaged molecules activate several signaling pathways that are involved in cell survival, DNA repair, aging, inflammation, and apoptosis $[5,6]$. 
UV-induced inflammatory processes are the primary event facilitating photocarcinogenesis through the activation of the transcription factors nuclear factor-kappa B (NF- $\mathrm{kB}$ ), hypoxia-inducible factor- 1 alpha (HIF- $1 \alpha)$, and cyclooxygenase-2 (COX-2) as well as proinflammatory cytokines, such as TNF- $\alpha[7,8]$. The cellular adaptation toward cell survival or apoptosis in response to excessive ROS depends upon the collective outcomes and balance of signaling pathways, including PI3K/Akt, mitochondrion-dependent apoptosis pathways (e.g., cytochrome $\mathrm{c}$ release), MAPK and NF- $\mathrm{KB}[9,10]$. Thus, modifying these response pathways in relation to cell survival is crucial in protecting keratinocytes from oxidative skin damage.

The use of UVB-preventive agents prior to developing skin cancer has been extensively investigated based on these well-established signal transduction markups. Incorporating natural antioxidants from plants and marine extracts into skin care products is becoming an important research focus for anti-aging purposes and the prevention of skin cancer [11]. Synthetic sunscreen works synergistically with natural antioxidants to maintain redox homeostasis and protect against skin cell damage from UVB radiation [12].

This study selected Amla or Indian gooseberry, scientifically known as Phyllanthus emblica L. (PE, syn. Emblica officinalis Gaertn.; Family Phyllanthaceae) because of its ethnopharmacological uses for more than 5000 years in Ayurvedic medicine originated in India [13]. The plant is cultivated and distributed to nearby countries such as Bangladesh, China, Thailand and other Southeast Asian countries. A great number of studies demonstrate health benefits of phytochemicals extracted from various parts of the plant, especially the fruits, which contain phenolics, flavonoids, tannins, and vitamins that strongly associated with the antioxidant activities, anti-inflammation, anti-diabetes, anticancer, and neuroprotective properties [14]. Although some of the pharmacological properties of PE have been studied, the dermato-protective properties of PE related to UVB-induced inflammation have not been reported. Thus, we assessed the anti-inflammatory and anti-apoptotic effects of PE during exposure to UVB radiation in the spontaneously transformed aneuploid immortal keratinocyte cell line ( $\mathrm{HaCaT})$, which has been extensively used as a model for in vitro studies on the UVB-induced damage of adult human keratinocytes [15].

\section{Materials and Methods}

\subsection{Materials}

Dulbecco's modified Eagle's medium (DMEM) without phenol red, fetal bovine serum (FBS), penicillin/streptomycin, and trypsin $(2.5 \%)$ were obtained from Gibco ${ }^{\circledR}$ (Thermo Fisher Scientific, Waltham, MA, USA). 3-(4,5-Dimethylthiazol-2-yl)-2,5-diphenyltetrazolium bromide (MTT) reagent was procured from Bio Basic (Amherst, NY, USA). The antioxidant standards for the HPLC analysis together with other chemicals and buffers, such as DMSO, dichloro-dihydro-fluorescein diacetate (DCFH-DA), dihydroethidium (DHE), and Purpald $^{\circledR}$, were obtained from Sigma-Aldrich (Merck, Darmstadt, Germany).

The anti-mouse IgG conjugated with HRP was purchased from Invitrogen (Thermo Fisher Scientific, Waltham, MA, USA). All the antibodies for the Western blot experiments were obtained from Cell Signaling Technology ${ }^{\circledR}$ (Danvers, MA, USA.). All the other reagents and chemicals were purchased from Merck ${ }^{\circledR}$ (Darmstadt, Germany). The cell culture wares, including plates and flasks (polystyrene coated), were obtained from Nunc Cell Culture ${ }^{\circledR}$ (Thermo Fisher Scientific, Waltham, MA, USA).

\subsection{PE Fruit Juice Extract Preparation}

PE was harvested from the same location as described in a previous study by Chularojmontri et al. [16]. The extraction was performed under semi-sterile conditions. PE fruits were washed with sterile water, and the seeds were discarded. PE fruit juice was obtained using a compact juice extractor and then filtered through sterile Whatman filter paper no. 1 (GE Healthcare, Chicago, IL, USA) three times using laboratory filtration equipment and dried to a powder by lyophilization. The PE crude extract powder was kept at $-40{ }^{\circ} \mathrm{C}$ until further use. A stock solution of PE $(10 \mathrm{mg} / \mathrm{mL})$ was prepared freshly for each experiment 
by dissolving $10 \mathrm{mg}$ of PE into $1 \mathrm{~mL}$ of sterile Milli- $\mathrm{Q}^{\circledR}$ type 1 ultrapure water (Merck Millipore, Burlington, MA, USA) and diluting the solution with cell culture medium to 10, 50 , and $100 \mu \mathrm{g} / \mathrm{mL}$.

\subsection{Analysis of Antioxidant Compounds by High-Performance Liquid Chromatography (HPLC)}

The common phytoantioxidant constituents of PE were quantitatively analyzed using a Shimadzu chromatographic system (Shimadzu, Kyoto, Japan) consisting of an LC pump (LC-20AD), autosampler (SIL-20AC HT), HPLC column oven (CTO-20A), UV-VIS photodiode array detector (SPD-M20A), system controller (CBM-20A), LC solution software, and Inertsil ${ }^{\circledR}$ ODS-3 reversed-phase C18 analytical column (GL, Tokyo Sciences, Japan). To prevent the degradation of antioxidant compounds, the standard and sample solutions were precooled in an autosampler cooler at $15{ }^{\circ} \mathrm{C}$, while the column temperature was adjusted to $40{ }^{\circ} \mathrm{C}$ with a low-pressure gradient mode. The mobile phases for analysis were acetonitrile, methanol, Milli- $\mathrm{Q}^{\circledR}$ type 1 ultrapure water (Merck Millipore, Burlington, MA, USA), and $20 \mathrm{mM}$ phosphate buffer, $\mathrm{pH} 2.5$ (PB). The standard compounds consisting of ascorbic acid, chlorogenic acid, ellagic acid, gallic acid, phyllanthin, and quercetin were used as references for the generation of standard curves. All the standards were prepared as stock solutions at $10 \mathrm{mg} / \mathrm{mL}$ and diluted to $6.25,12.5,25,50$, and $100 \mu \mathrm{g} / \mathrm{mL}$.

Ascorbic acid was dissolved in HPLC-grade water, while each standard stock solution of chlorogenic acid, quercetin, and phyllanthin was dissolved and diluted in 100\% methanol. A gallic acid stock solution was first prepared in 100\% methanol and diluted to 12.5, 25, 50, 100 , and $200 \mu \mathrm{g} / \mathrm{mL}$ with methanol/HPLC-grade water at a ratio of 1:1. Ellagic acid was dissolved in $0.1 \mathrm{M} \mathrm{NaOH}$ followed by serial dilutions in $50 \%$ methanol. Dry PE powder was dissolved in HPLC-grade water to prepare the stock solution $(50 \mathrm{mg} / \mathrm{mL})$ and diluted with $50 \%$ methanol for HPLC analysis. The optimization of the chromatographic conditions was described by Sawant et al. [17,18]. Briefly, the photodiode array detector wavelength was set at 190-800 $\mathrm{nm}$. The determination of ascorbic acid in PE applied isocratic elution with PB at the flow rate of $0.5 \mathrm{~mL} / \mathrm{min}, \lambda 243 \mathrm{~nm}$, and 15 -min running time. The chromatographic condition of ellagic acid determination in PE included the mobile phase consisting of $70 \% \mathrm{~PB}$ (eluent $\mathrm{A}$ ), and $30 \%$ acetonitrile (eluent $\mathrm{B}$ ). The isocratic elution was used for the detection at flow rate $1 \mathrm{~mL} / \mathrm{min}, \lambda 253 \mathrm{~nm}$, and 10-min running time. The determination of gallic acid was performed under isocratic elution at the flow rate $1.5 \mathrm{~mL} / \mathrm{min}, \lambda 270 \mathrm{~nm}$, and $10-\mathrm{min}$ running time. The mobile phase contained $95 \%$ PB (eluent A) and 5\% acetonitrile (eluent B). The sample and standard solutions of chlorogenic acid, quercetin, and phyllanthin were analyzed concomitantly using gradient elution, which included PB (eluent A) and acetonitrile (eluent $B$ ) as a mobile phase at the flow rate $1.5 \mathrm{~mL} / \mathrm{min}$, and running time $30 \mathrm{~min}$. The gradient elution was performed following the condition: $0-3 \mathrm{~min}(0-10 \% \mathrm{~B})$; 3-15 $\min (0-90 \%$ B); $15-21 \mathrm{~min}(90 \% \mathrm{~B}) ; 21-22 \min (90-10 \% \mathrm{~B}) ; 22-30 \mathrm{~min}(10 \% \mathrm{~B})$. The UV detection wavelength of chlorogenic acid, quercetin, and phyllanthin were set at $325 \mathrm{~nm}$, $255 \mathrm{~nm}$, and $280 \mathrm{~nm}$, respectively. The samples and standard volume of all compounds were constantly injected at $20 \mu \mathrm{L}$. The retention time of standard ascorbic acid, chlorogenic acid, ellagic acid, gallic acid, phyllanthin, and quercetin were appeared at 9.796, 8.626, 4.986, $4.956,17.187$, and 12.677 , respectively.

\subsection{In Vitro Analysis of ROS-Scavenging Activities and the Antioxidant Capacities of PE}

We performed a hydroxyl radical scavenging assay, superoxide anion radical scavenging assay, hydrogen peroxide scavenging assay, ferric reducing antioxidant power (FRAP) assay, and oxygen radical absorbance capacity (ORAC) assay following our previous study procedures as reported by Jarisarapurin et al. [19].

\subsection{Cell Culture}

A spontaneously immortalized aneuploid human keratinocyte cell line, HaCaT, passage number 32, was obtained from CLS Cell Lines Service GmbH (Eppelheim, Germany). The HaCaT cells were grown in DMEM supplemented with 10\% FBS and 1\% antibiotics 
(100 units/mL of penicillin/streptomycin) and incubated at $37{ }^{\circ} \mathrm{C}$ in a $5 \% \mathrm{CO}_{2}$ incubator (NuAire, Plymouth, MN, USA). The cell culture medium was changed every 3 days, and the cells were subcultured at $80 \%$ confluency. Only early cell passages $(<50)$ were used for the assays.

\subsection{Cell Treatment and UVB Irradiation}

$\mathrm{HaCaT}$ cells were pretreated with various concentrations of PE $(0,10,50,100$, and $1000 \mu \mathrm{g} / \mathrm{mL}$ ) and further cultured for $6 \mathrm{~h}$ before UVB irradiation. The non-UV control groups were treated with cell culture medium only. Prior to UVB exposure $\left(40 \mathrm{~mJ} / \mathrm{cm}^{2}\right)$ with the BIO SUN Ultraviolet Irradiation System (Vilber Lourmat, Marne La Vallée, France), the cells were washed twice with $4{ }^{\circ} \mathrm{C}$ cold phosphate buffer saline (PBS). Then, an adequate amount of cold PBS was layered on the cells to cover the cells, in 100-mm culture dishes. After UVB irradiation, the cells were washed again with cold PBS, and then, the PBS was replaced with fresh DMEM and the cells were incubated for $18 \mathrm{~h}$ for further experiments.

\subsection{Cell Viability Assay}

HaCaT cells were seeded at $2 \times 10^{4}$ cells/well in 96-well plates and incubated overnight. After $6 \mathrm{~h}$ of PE incubation and UVB exposure, the cells were cultured for another $18 \mathrm{~h}$. Then, MTT reagent was added into the medium at a final concentration of $0.25 \mathrm{mg} / \mathrm{mL}$, and incubation was continued for $3 \mathrm{~h}$. The medium was removed, and the remaining formazan crystals were dissolved with 100\% DMSO. The cellular viability of the $\mathrm{HaCaT}$ cells was determined by reading the absorbance at $550 \mathrm{~nm}$ using a SpectraMax ${ }^{\circledR}$ M2e microplate reader (Molecular Devices, San Jose, CA, USA) and calculated as the percentage of cell viability with reference to the vehicle control wells $(100 \%)$.

\subsection{Determination of Intracellular ROS Generation}

$\mathrm{HaCaT}$ cells were grown in $60-\mathrm{mm}$ culture dishes at $7 \times 10^{5}$ cells/well. After PE treatment and UVB exposure, the cells were stained with $25 \mu \mathrm{g} / \mathrm{mL} \mathrm{DCFH-DA}$ for $30 \mathrm{~min}$ at $37^{\circ} \mathrm{C}$ in the dark [18]. The cells were collected by trypsinization, centrifuged at $300 \mathrm{~g}$ for $5 \mathrm{~min}$, and washed twice with PBS. Then, the cell concentration was adjusted to approximately 500 cells / $\mu$ L in DPBS, and the cells were analyzed for intracellular ROS fluorescence with a Guava ${ }^{\circledR}$ easyCyte 8HT Benchtop Flow Cytometer (Millipore-Merck, Darmstadt, Germany). The data are shown as percentages of the relative mean fluorescence intensity.

\subsection{Detection of Intracellular Hydrogen Peroxide Levels}

An Amplex ${ }^{\circledR}$ Red Hydrogen Peroxide/Peroxidase Assay Kit (Thermo Fisher Scientific, Waltham, MA, USA) was used to detect the release of $\mathrm{H}_{2} \mathrm{O}_{2}$ from the cells. HaCaT cells were seeded in 96-well plates and cultivated overnight. Thirty minutes after UVB irradiation, a reaction mixture containing $50 \mu \mathrm{M}$ Amplex ${ }^{\circledR}$ Red reagent and $0.1 \mathrm{U} / \mathrm{mL}$ HRP in reaction buffer was added to the culture dishes, and the reaction was incubated for $10 \mathrm{~min}$. The reaction was protected from light until the end of the experiment. Finally, the cellular fluorescence intensity was measured using a microplate reader (SpectraMax ${ }^{\circledR}$ M2e Multimode Microplate Readers, Molecular Devices) at the excitation/emission wavelengths of $530 / 590 \mathrm{~nm}$.

\subsection{Detection of Intracellular Superoxide Levels}

This assay used dihydroethidium (DHE) to detect the superoxide generated within the cells [20]. DHE is oxidized by superoxide and converted to a blue fluorescent compound in the cytosol. To initiate the experiment, HaCaT cells were grown in 96-well plates at $2 \times 10^{4}$ cells/well. After PE pretreatment and UVB irradiation, the cells were probed with $10 \mu \mathrm{M}$ DHE for $30 \mathrm{~min}$ and protected from light. The cells were washed twice with PBS and analyzed under a fluorescence microplate reader at the emission/excitation wavelengths of 488/610 nm. 


\subsection{Catalase (CAT) Activity Assay}

The assay was performed as previously described with certain modifications [21]. Briefly, the cell lysates were collected and mixed with the test buffer in a 96-well plate, and $35 \mathrm{mM} \mathrm{H}_{2} \mathrm{O}_{2}$ was added to the reaction mixture, which was then incubated at room temperature for $10 \mathrm{~min}$ on a shaker. Next, we added $3 \mathrm{mg} / \mathrm{mL}$ of Purpald ${ }^{\circledR}$ (Sigma-Aldrich, St. Louis, MO, USA) in $0.5 \mathrm{M} \mathrm{KOH}$ to each well. After the chromogenic substance was generated, potassium periodate was added to stop the reaction. The catalase activity was measured by reading the absorbance at $540 \mathrm{~nm}$ using a microplate reader and calculated from formaldehyde standard curves.

\subsection{Super Oxide Dismutase (SOD) Activity Assay}

The SOD activity was determined using a SOD Assay Kit-WST (Sigma-Aldrich, St. Louis, MO, USA). Protein lysates were prepared as described by the manufacturer's instructions. Briefly, the protein lysates were mixed with WST and enzyme working solution and incubated for $20 \mathrm{~min}$ at $37^{\circ} \mathrm{C}$. After incubation, the amount of water-soluble formazan dye was measured according to the absorbance at $450 \mathrm{~nm}$ using a microplate reader.

\subsection{Glutathione Peroxidase (GPx) Activity Assay}

A GPx assay was performed according to the method described by Wheeler et al. with minor modifications [20]. Briefly, $100 \mu \mathrm{L}$ of GPx assay buffer (50 mM Tris buffer, $\mathrm{pH} 7.4$, and $1 \mathrm{mM}$ EDTA) and $20 \mu \mathrm{L}$ of protein lysate were added to $96-$ well plates. One hundred microliters of the co-substrate mixer $(0.6 \mathrm{mg} / \mathrm{mL}$ NADPH, $0.4 \mathrm{mg} / \mathrm{mL} \mathrm{GSH}$, and 5 units $/ \mathrm{mL}$ glutathione reductase) was then added to each well, followed by $20 \mu \mathrm{L}$ of GPx substrate containing $15 \mathrm{mM}$ cumene hydroperoxide. The GPx activity was monitored according to the absorbance at $340 \mathrm{~nm}$.

\subsection{Apoptotic Analysis by Hoechst 33,342 and Propidium Iodide (PI) Staining}

After the HaCaT cells were pretreated with PE and exposed to UVB, the cells were washed twice with PBS and incubated with $1 \mu \mathrm{g} / \mathrm{mL}$ Hoechst 33,342 in PBS for $10 \mathrm{~min}$. The cells were then washed with PBS and double-stained with $1 \mu \mathrm{g} / \mathrm{mL}$ PI in PBS for $10 \mathrm{~min}$. After the removal of the dyes, fresh PBS was added to cover the cells, and the apoptotic/necrotic cells were detected under a fluorescence microscope. At least three randomized pictures were collected, and the apoptotic nuclei were counted using ImageJ $1.42[22]$.

\subsection{5. $P G E_{2}$ Detection}

A Prostaglandin $\mathrm{E}_{2}$ Parameter Assay Kit (R\&D Systems Inc, Minneapolis, MN, USA) was used to measure the release of $\mathrm{PGE}_{2}$ in the cell culture supernatant. The preparation of the cell lysate and assay procedures were performed according to the manufacturer's instructions. The $\mathrm{PGE}_{2}$ concentrations $(\mathrm{pg} / \mathrm{mL})$ in the samples were calculated from the standard $\mathrm{PGE}_{2}$ curve.

\subsection{Western Blot Analysis}

HaCaT cells were seeded in 60-mm dishes. After the cell treatments, the total cytosolic proteins were collected in RIPA lysis buffer, while the nuclear lysates were extracted by using the nuclear extraction kit No. 10009277 (Cayman Chemical, Ann Arbor, MI, USA). The protein concentrations were determined using the Bio-Rad protein assay dye reagent (Bio-Rad Laboratories Ltd., Hercules, CA, USA). The proteins of interest were separated by SDS-PAGE and transferred onto Amersham Hybond P 0.45 PVDF blotting membranes (GE Healthcare, Chicago, IL, USA) using a mini-PROTEAN Tetra system and PowerPac ${ }^{\mathrm{TM}} \mathrm{HC}$ power supply (Bio-Rad Laboratories Ltd., Hercules, CA, USA).

The membranes were blocked with blocking buffer $(5 \%$ BSA or $5 \%$ skim milk in TBST) for $1 \mathrm{~h}$ before incubation with 1:1000 dilutions of primary antibodies, including those against COX-2 (\#12282), cytochrome c (cyt c, \#11940), NF-kB (\#4764), $\beta$-actin (\#3700), 
phospho-c-Jun (p-c-Jun) (\#9164), phospho-Akt (p-Akt) (\#4051), Akt (\#9272), phospho-p38 (p-p38) (\#9215), and p38 (\#8690) (Cell Signaling Technology, Danvers, MA, USA), overnight. Then, the membranes were washed with TBST and probed with HRP-conjugated secondary antibody (1:3000) for $1 \mathrm{~h}$.

Next, the membranes were washed with TBST and probed with Amersham ECL Prime chemiluminescent detection reagent (GE Healthcare, USA). The protein bands were detected and visualized using a gel documentation system (UVITEC, Cambridge, UK) and analyzed using Image 1.42 [21]. Among five different time points $(0,15,30,60$, and $120 \mathrm{~min}$ ), the peak protein expression after UVB irradiation and PE pretreatment was observed at $30 \mathrm{~min}$ for p-Akt, Akt, p-p38, and p38 and at $120 \mathrm{~min}$ for NF-kB, and p-c-Jun. A time-course study of COX-2 expression and cyt $\mathrm{c}$ release was performed at $0,6,12,18$, and $24 \mathrm{~h}$, and $24 \mathrm{~h}$ was selected for detection.

\subsection{Statistical Analysis}

All the data are reported as the mean \pm SEM. The statistical tests were performed with a means comparison by one-way analysis of variance (ANOVA) with the Dunnett post hoc test.

\section{Results}

\subsection{Quantification of Phytoantioxidant Contents in PE}

The compositions of the six selected phytoantioxidants in PE were identified using HPLC to compare the specific absorption spectra and the retention times between the reference standards and samples. The retention times of the standards, including ascorbic acid, chlorogenic acid, ellagic acid, gallic acid, phyllanthin, and quercetin were 9.796, 8.626, 4.986, 4.956, 17.187, and 12.677, respectively. Shown in Figure 1 are the HPLC chromatograms of the standards (Figure S1a,c,e,g,i,k) and samples (Figure S1b,d,f,h,j,l).

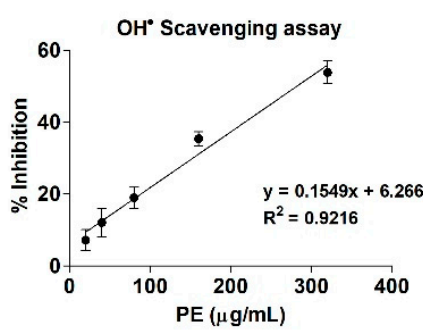

(a)

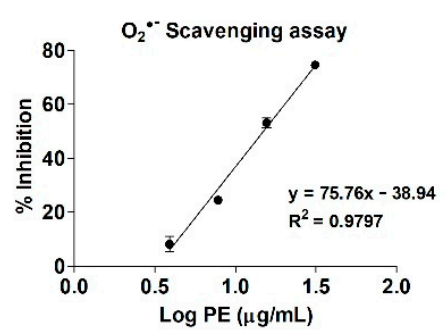

(b)

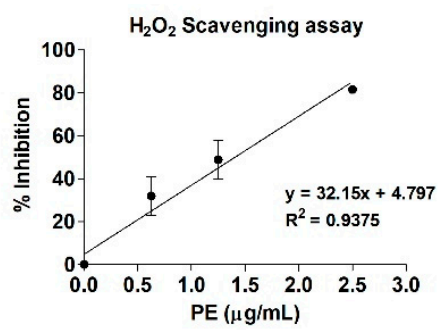

(c)

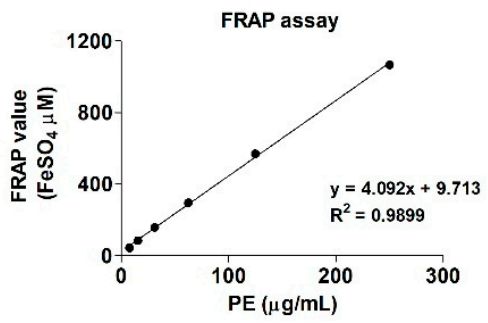

(d)

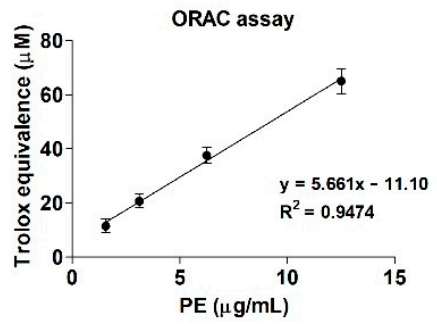

(e)

Figure 1. The linear regression of specific reactive oxygen species (ROS)-scavenging activities and antioxidant capacities of PE. (a) $\mathrm{OH}^{\bullet}$, (b) $\mathrm{O}_{2}^{\bullet-}$, and (c) $\mathrm{H}_{2} \mathrm{O}_{2}$ scavenging activities. Antioxidant activities according to (d) FRAP and (e) ORAC.

The phytoantioxidant contents were calculated from the standard calibration curves for each compound. The phytoantioxidants found in PE $(\% w / w)$ were ascorbic acid $(1.5886 \%)$, ellagic acid $(0.6255 \%)$, gallic acid $(0.3702 \%)$, chlorogenic acid $(0.0145 \%)$, and quercetin $(0.0009 \%)$. Unexpectedly, the peak of phyllanthin was not detected in the HPLC 
histogram of the PE sample, although it is commonly found in the plants of the genus Phyllanthus (Figure S1j).

\subsection{The Antioxidant Properties of PE}

The antioxidant capacities of $\mathrm{PE}$ were tested in terms of specific scavenging activities $\left(\mathrm{OH}^{\bullet}, \mathrm{O}_{2}{ }^{\bullet-}\right.$, and $\left.\mathrm{H}_{2} \mathrm{O}_{2}\right)$ and the total ROS-scavenging capability (FRAP and ORAC assays). Dose-dependent associations were found between the PE concentration and antioxidant activities, with significant, positive linear correlations in all the antioxidant assays $(p<0.05$, Figure 1). The ability of PE to scavenge ROS was apparent in the concentrations of PE that inhibited half the maximal production of $\mathrm{ROS}\left(\mathrm{IC}_{50}, \mu \mathrm{g} / \mathrm{mL}\right)$. PE best inhibited specific ROS in the order $\mathrm{H}_{2} \mathrm{O}_{2}>\mathrm{O}_{2}{ }^{\bullet-}>\mathrm{OH}^{\bullet}$ (Table 1). PE also demonstrated strong antioxidant properties according to both the FRAP and ORAC assays.

Table 1. The antioxidant activities and antioxidant capacities of PE.

\begin{tabular}{ccc}
\hline ROS Scavenging Activity & $\mathrm{IC}_{\mathbf{5 0}}(\boldsymbol{\mu \mathbf { g }} / \mathbf{m L})$ & Linear Regression Equation \\
\hline Hydroxyl radical & $282.49 \pm 17.59$ & $\mathrm{y}=0.1549 \mathrm{x}+6.266$ \\
Superoxide anion & $14.94 \pm 0.15$ & $\mathrm{y}=75.46 \mathrm{x}-38.94$ \\
Hydrogen peroxide & $1.46 \pm 0.37$ & $\mathrm{y}=32.15 \mathrm{x}+4.797$ \\
\hline Antioxidant capacity & $(\boldsymbol{\mu m o l} / \mathbf{g})$ & Linear regression equation \\
\hline FRAP value (FeSO 4 equivalent) & $4279.86 \pm 269.84$ & $\mathrm{y}=4.092 \mathrm{x}+9.713$ \\
ORAC (Trolox equivalent) & $5480 \pm 554.43$ & $\mathrm{y}=5.661 \mathrm{x}-11.10$ \\
\hline
\end{tabular}

\subsection{Cytoprotective Effect of $P E$}

The cell viability of HaCaT cells at $18 \mathrm{~h}$ after exposure to different doses of UVB irradiation $\left(0,20,40,60,80\right.$, and $\left.100 \mathrm{~mJ} / \mathrm{cm}^{2}\right)$ is shown in Figure S2a. UVB significantly induced cytotoxicity in a dose-dependent manner at doses of 40 to $1000 \mathrm{~mJ} / \mathrm{cm}^{2}$. Thus, the UVB dose of $40 \mathrm{~mJ} / \mathrm{cm}^{2}$, which decreased the cell viability to $75.86 \% \pm 3.81 \%$, was selected for the UVB treatment in further experiments. Six-hour PE pretreatment alone at concentrations up to $1000 \mu \mathrm{g} / \mathrm{mL}$ did not change the cell viability; however, $\mathrm{PE}$ at $50 \mu \mathrm{g} / \mathrm{mL}$ significantly increased the cell viability to $93.77 \% \pm 4.71 \%$ in $\mathrm{HaCaT}$ cells exposed to UVB (Figure S2b).

\subsection{Effects of PE on UVB-Induced ROS, $\mathrm{O}_{2}{ }^{\bullet-}$, and $\mathrm{H}_{2} \mathrm{O}_{2}$ Production}

HaCaT cells exposed to UVB irradiation showed a significant 2.9-fold increase in intracellular ROS $(290.76 \% \pm 23.90 \%)$, whereas a decline of ROS levels was observed in UVB-irradiated HaCaT cells pretreated with PE (Figure 2a,b). The cells incubated with PE at $100 \mu \mathrm{g} / \mathrm{mL}$ before UVB exposure showed a significant attenuation of ROS production down to $181.85 \% \pm 8.38 \%$ when compared with no PE treatment.

UVB significantly activated the generation of $\mathrm{O}_{2}{ }^{\bullet-}$ in $\mathrm{HaCaT}$ cells to $124.99 \% \pm 0.89 \%$ (Figure 2c). On the contrary, PE treatment alone $(10,50$, and $100 \mu \mathrm{g} / \mathrm{mL})$ dose-dependently decreased cellular $\mathrm{O}_{2}{ }^{\bullet-}$ accumulation down to $89.82 \% \pm 3.37 \%, 80.38 \% \pm 1.96 \%$, and $68.50 \% \pm 5.47 \%$, respectively (Figure $2 \mathrm{c}$ ), and this trend was preserved when UVB was applied to the cells. PE at 50 and $100 \mu \mathrm{g} / \mathrm{mL}$ significantly suppressed superoxide production down to $90.92 \% \pm 5.80 \%$ and $82.29 \% \pm 3.47 \%$, respectively. 


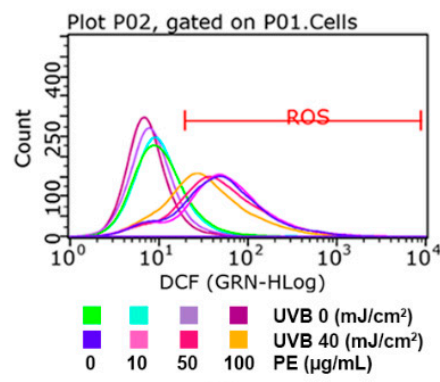

(a)

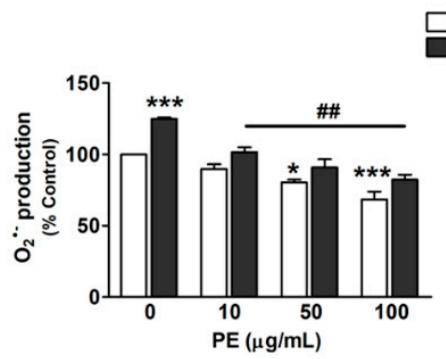

(c)

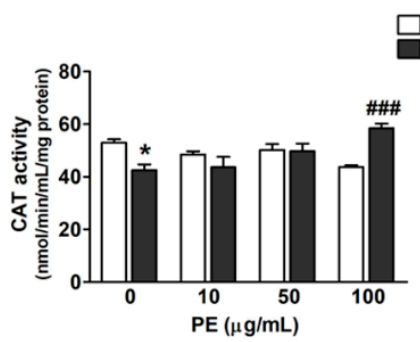

(e)

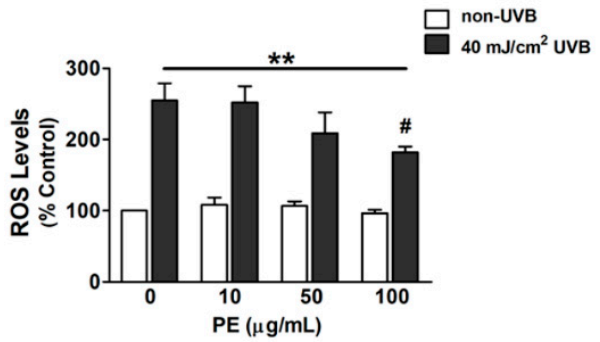

(b)

non-UVB
$40 \mathrm{~mJ} / \mathrm{cm}^{2} \mathrm{UVB}$

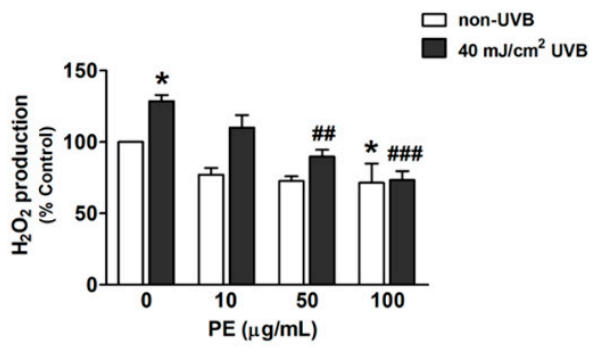

(d)

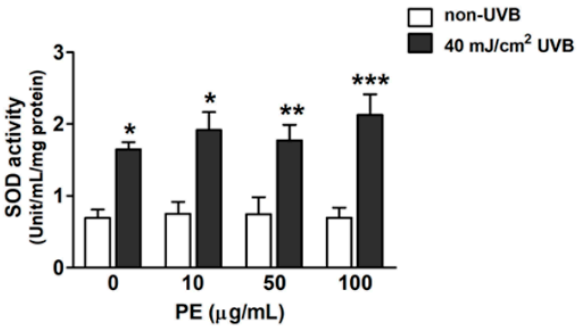

(f)

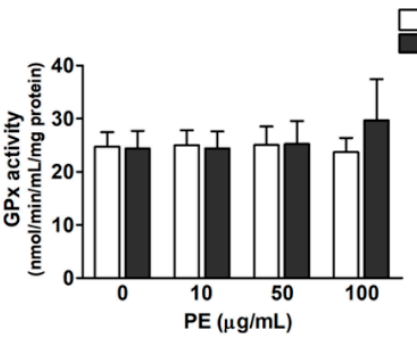

(g)

Figure 2. The effect of PE on UVB-induced intracellular ROS production and enzymatic antioxidant activity in HaCaT cells. (a) A fluorescent intensity diagram of DCFH-DA signals as detected by flow cytometry. (b) The calculated relative intracellular ROS levels in each sample group compared with those in the non-UVB group. (c) The intracellular superoxide $\left(\mathrm{O}_{2}{ }^{\bullet-}\right)$ production in HaCaT cells after PE preincubation and UVB exposure. (d) The intracellular $\mathrm{H}_{2} \mathrm{O}_{2}$ production in $\mathrm{HaCaT}$ cells following the PE incubation and UVB irradiation. (e) CAT activity; (f) SOD activity; (g) GPx activity. The data are shown as the mean \pm SEM. ${ }^{*}, p<0.05 ;{ }^{* *}, p<0.01$; and ${ }^{* * *}, p<0.001$, when compared to the non-UVB group; ${ }^{\prime}, p<0.05$; ${ }^{\# \#}, p<0.01$; and $\# \#, p<0.001$, when compared to the UVB-exposed group.

Similarly to the generation of $\mathrm{O}_{2}{ }^{\bullet-}$, the release of $\mathrm{H}_{2} \mathrm{O}_{2}$ in HaCaT cells was increased by UVB to $128.61 \% \pm 8.97 \%$ (Figure $2 \mathrm{~d}$ ). After treatment with various concentrations of PE, the $\mathrm{H}_{2} \mathrm{O}_{2}$ production was decreased in a dose-dependent manner to $110.02 \% \pm 12.06 \%$, $89.85 \% \pm 11.74 \%$, and $73.41 \% \pm 18.26 \%$, for PE at 10,50 , and $100 \mu \mathrm{g} / \mathrm{mL}$, respectively. 


\subsection{Effects of PE on UVB-Induced Antioxidant Enzyme Activities}

The UVB-irradiated cells showed a significant decrease in CAT activity to $42.58 \pm 2.12$ $\mathrm{nmol} / \mathrm{min} / \mathrm{mL} / \mathrm{mg}$ protein $(80.27 \% \pm 2.13 \%$ when compared with the non-UVB group, Figure 2e). Only PE at the highest concentration used in the experiment $(100 \mu \mathrm{g} / \mathrm{mL})$ significantly increased the CAT activity, to $58.46 \pm 1.73 \mathrm{nmol} / \mathrm{min} / \mathrm{mL} / \mathrm{mg}$ protein, which represented a 30\% increase from that in the UVB-exposed group (Figure 2e). In contrast to its effects on the CAT activity, UVB enhanced the SOD activity by 2.4-fold, while PE pretreatment did not affect the elevation of SOD activity (Figure 2f). The GPx activity was not changed by either UVB exposure or PE treatment (Figure $2 \mathrm{~g}$ ).

\subsection{Effect of PE on UVB-Induced Apoptosis in HaCaT Cells}

The apoptotic morphological changes in HaCaT cells after UVB exposure included cellular shrinkage, DNA condensation, and the presence of apoptotic bodies (Figure 3a). Necrotic cell death was not detected by PI staining (data not shown). UVB irradiation significantly increased the apoptotic cells 5.7 -fold, to $20.36 \% \pm 0.87 \%$, when compared with those in the non-UVB group, at $3.58 \% \pm 0.49 \%$. PE pretreatment at the concentrations of 10,50 , and $100 \mu \mathrm{g} / \mathrm{mL}$ significantly decreased the percentages of apoptotic cell death in a dose-dependent manner to $15.59 \% \pm 1.21 \%, 10.18 \% \pm 0.83 \%$, and $7.65 \% \pm 0.28 \%$, respectively (Figure 3b).

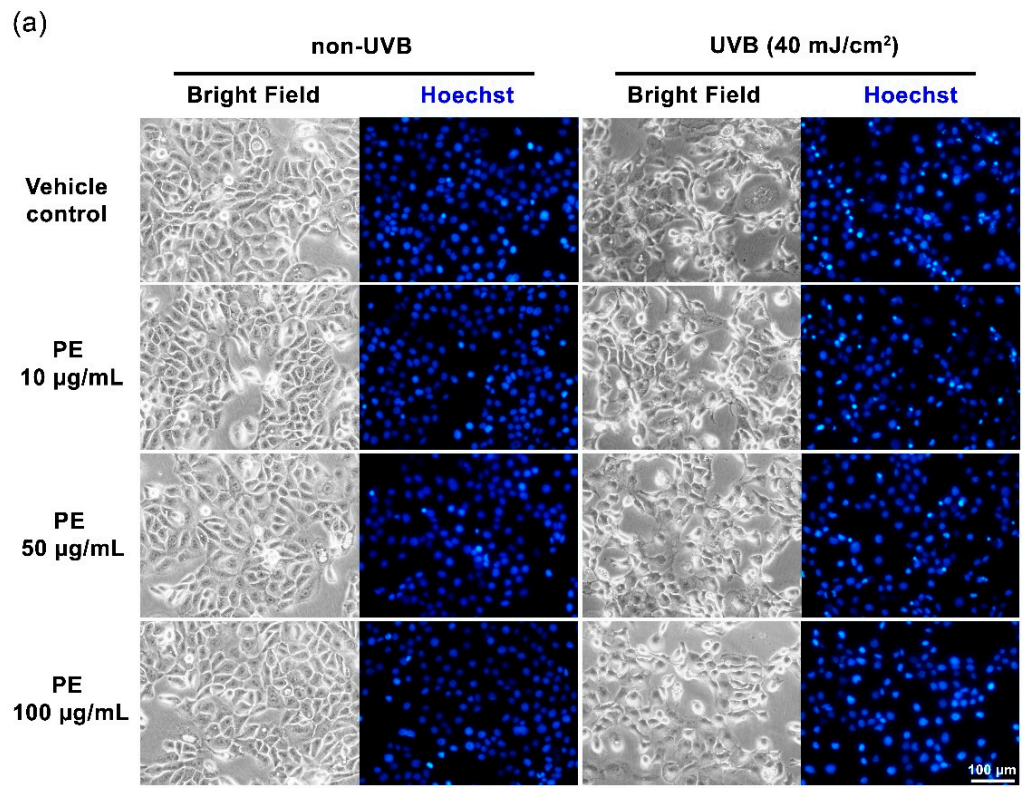

(b)

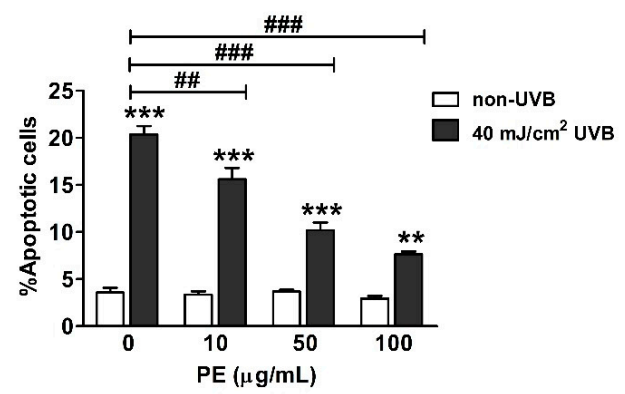

Figure 3. The effects of PE on UVB-induced apoptosis in HaCaT cells. (a) The morphological changes of HaCaT cells as observed under inverted light (bright field) and fluorescent microscopy (Hoechst staining). (b) The calculated percentages of apoptotic cells after PE and UVB irradiation. The data are shown as the mean \pm SEM. ${ }^{* *}, p<0.01$, and ${ }^{* *}, p<0.001$, when compared to the non-UVB group; \#\#, $p<0.01$, and ${ }^{\# \#}, p<0.001$, when compared to the UVB-exposed group. Scale bar, $100 \mu \mathrm{m}$. 
3.7. Time Course Effects Regarding UVB-Induced Inflammatory and Apoptotic Signaling Pathways in $\mathrm{HaCaT}$ Cells

The time-course study of the effect of UVB irradiation on keratinocyte inflammation and cell death is shown in Figures 4 and S3. The UVB-activated COX-2 expression and cyt $\mathrm{c}$ release were found to be significantly different from non-UVB treated cells at $24 \mathrm{~h}$ (Figure $4 \mathrm{a}-\mathrm{c}$ ). The changes in signaling through $\mathrm{c}-\mathrm{Jun}$ and NF- $\mathrm{kB}$ were the highest at $120 \mathrm{~min}$ (Figure $4 \mathrm{a}, \mathrm{d}, \mathrm{e}$ ). For the detection of Akt and p38, the peaks of alterations occurred as early as $30 \mathrm{~min}$ (Figure $4 \mathrm{a}, \mathrm{f}, \mathrm{g}$ ). Therefore, the effects of PE on the signal transduction in HaCaT cells exposed to UVB were studied at $24 \mathrm{~h}$ for COX-2 and cyt c, 120 min for c-Jun and NF-kB, and 30 min for Akt and p38.

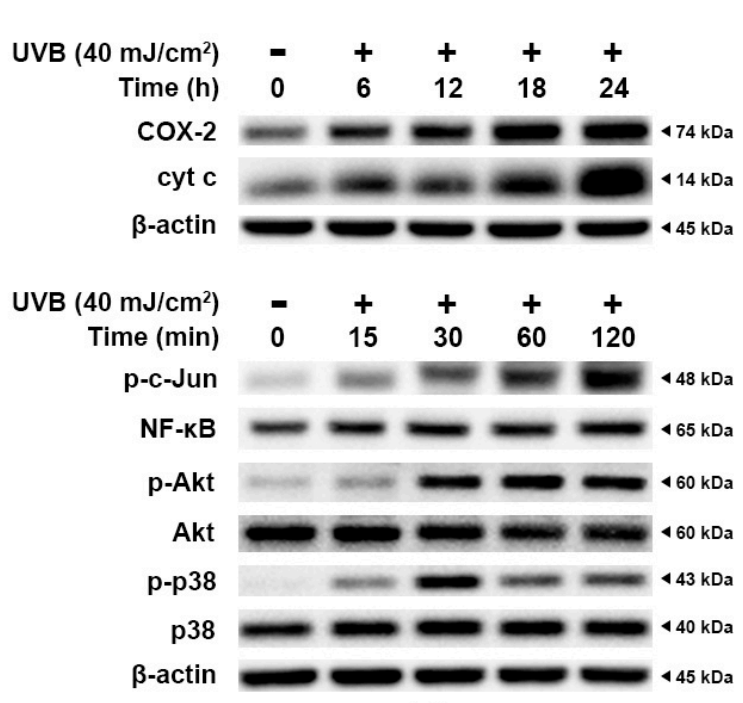

(a)

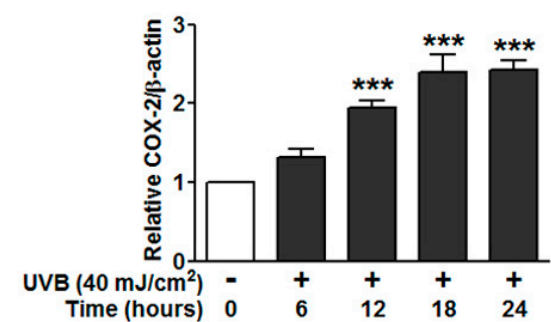

(b)

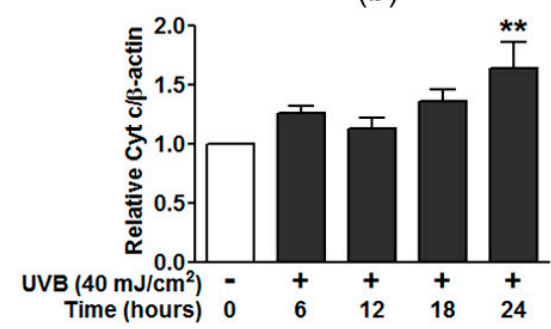

(c)

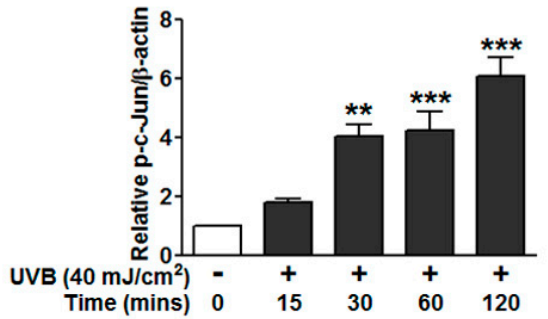

(d)

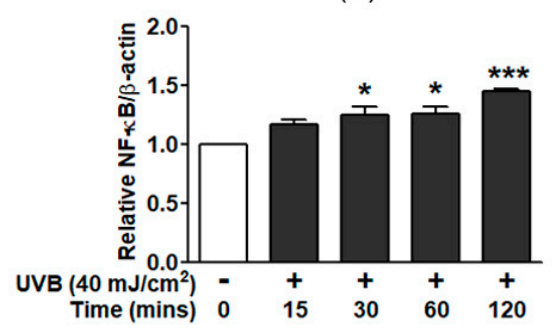

(e)

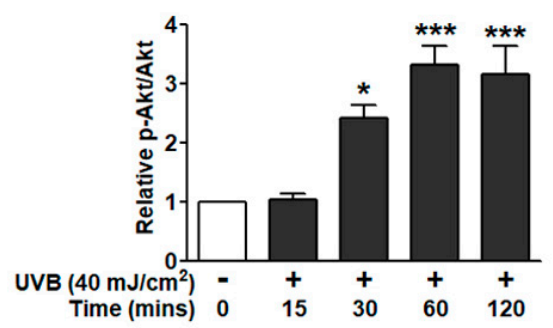

(f)

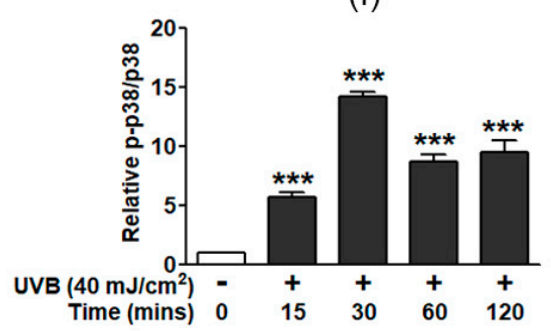

(g)

Figure 4. A time-course study of apoptotic and inflammatory signaling changes in HaCaT cells exposed to UVB. (a) Western blot bands for COX-2 expression and cyt c levels detected at 0, 6, 12,18 , and $24 \mathrm{~h}$ and $\mathrm{p}-\mathrm{c}-J u n, \mathrm{NF}-\mathrm{kB}, \mathrm{Akt}$, and p38 detected at 0 to $120 \mathrm{~min}$ after UVB irradiation. (b) Graphical presentation of the calculated ratios of COX-2/ $\beta$-actin and (c) cyt $c / \beta$-actin. (d) $p$ $\mathrm{c}-J u n / \beta$-actin, (e) NF-kB/ $\beta$-actin, (f) p-Akt/Akt, and (g) p-p38/p38. The data are shown as the mean $\pm \operatorname{SEM}(n=3){ }^{*}, p<0.05 ;^{* *}, p<0.01 ;{ }^{* * *}, p<0.001$, when compared to the non-UVB group. 


\subsection{Effect of PE on Inflammatory Responses to UVB}

The protective effect of $\mathrm{PE}$ on $\mathrm{HaCaT}$ cells against UVB-induced inflammation is shown in Figures 5 and S4. UVB significantly increased the COX- $2 / \beta$-actin ratio $3.51 \pm 0.28$ fold compared to that in the non-UVB group, while pretreatment with PE markedly mitigated the effect of UVB on COX-2 activation, and, in particular, $\mathrm{PE}$ at the concentrations of 50 and $100 \mu \mathrm{g} / \mathrm{mL}$ reduced the COX-2/ $\beta$-actin ratio to $2.20 \pm 0.33$ fold and $2.27 \pm 0.27$ fold, respectively (Figure $5 \mathrm{a}, \mathrm{b}$ ). The inflammatory nuclear signaling of c-Jun and NF- $\mathrm{\kappa B}$ in $\mathrm{HaCaT}$ cells was also altered by UVB exposure.

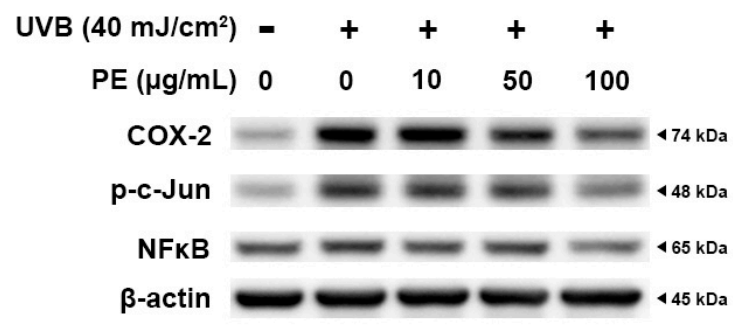

(a)

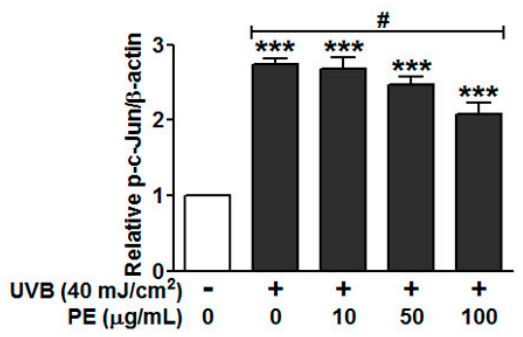

(c)

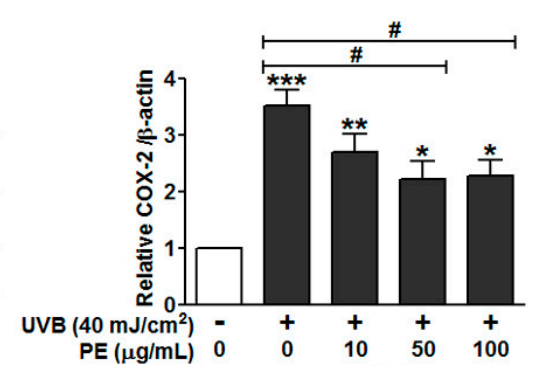

(b)

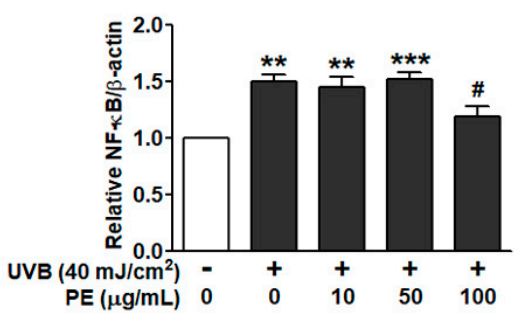

(d)

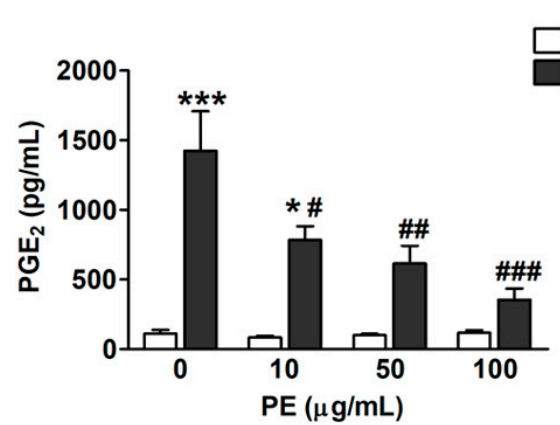

(e)

Figure 5. The effects of PE and UVB on the activation of COX-2, p-c-Jun, NF-kB, and Nrf2. (a) The protein bands of COX-2 and cyt $c$ in relation to $\beta$-actin. The relative ratios of the band intensity for (b) COX-2/ $\beta$-actin, (c) p-c-Jun / $\beta$-actin, and (d) NF- $\mathrm{kB} / \beta$-actin; (e) the levels of prostaglandin $\mathrm{E}_{2}$ $\left(\mathrm{PGE}_{2}\right)$. The data are shown as the mean $\pm \operatorname{SEM}(n=3) .{ }^{*}, p<0.05 ; * *, p<0.01$; and ${ }^{* * *}, p<0.001$, when compared to the non-UVB group; $\#, p<0.05$; \#\#, $p<0.01$; and ${ }^{\# \#,}, p<0.001$, when compared to the UVB-exposed group.

The phosphorylation of c-Jun (p-c-Jun) was increased $2.74 \pm 0.07$ fold by UVB; however, pretreating cells with PE at $100 \mu \mathrm{g} / \mathrm{mL}$ significantly decreased p-c-Jun levels, by $2.08 \pm 0.16$ fold, compared to those in the non-UVB group (Figure $5 c$ ). UVB increased the translocation of NF- $\mathrm{kB}$ by $1.50 \pm 0.06$-fold compared to that in the non-UVB group, whereas PE pretreatment at $100 \mu \mathrm{g} / \mathrm{mL}$ significantly decreased the NF- $\mathrm{kB} / \beta$-actin ratio by $1.18 \pm 0.10$-fold (Figure $5 \mathrm{~d}$ ).

The quantification of the important terminal inflammatory effector $\mathrm{PGE}_{2}$ is shown in Figure 5e. UVB markedly induced $\mathrm{PGE}_{2}$ production, up to $1423.4 \pm 283.4 \mathrm{pg} / \mathrm{mL}$ 
(a 12.64-fold increase), compared to that in the control group $(112.6 \pm 26.8 \mathrm{pg} / \mathrm{mL})$. The pretreatment of HaCaT cells with different PE concentrations $(10,50$, and $100 \mu \mathrm{g} / \mathrm{mL})$ significantly suppressed $\mathrm{PGE}_{2}$ production in a dose-dependent manner, which reduced the $\mathrm{PGE}_{2}$ levels down to $784.0 \pm 99.2,615.3 \pm 127.1$, and $355.7 \pm 79.8 \mathrm{pg} / \mathrm{mL}$, respectively.

\subsection{Influence of PE on Apoptotic Signaling in HaCaT Cells Exposed to UVB}

The cell survival and cell stress signals are presented as the relative ratios of $\mathrm{p}$ Akt/Akt, p-p38/p38, and cyt c/ $\beta$-actin in UVB-irradiated HaCaT cells compared to those in the non-UVB group (Figures 6 and S5). UVB-exposed HaCaT cells showed enhanced phosphorylation of Akt (1.42 \pm 0.17 fold); however, the pretreatment of cells with PE at 10, 50 , and $100 \mu \mathrm{g} / \mathrm{mL}$ dose-dependently attenuated Akt activation to the levels $0.88 \pm 0.08$, $0.80 \pm 0.05$, and $0.63 \pm 0.08$ fold, respectively (Figure 6a,b).

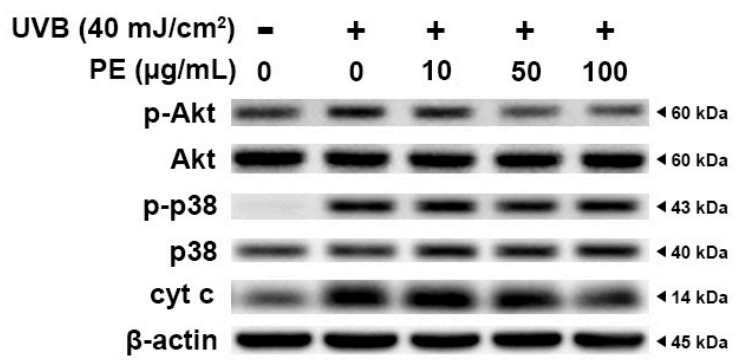

(a)

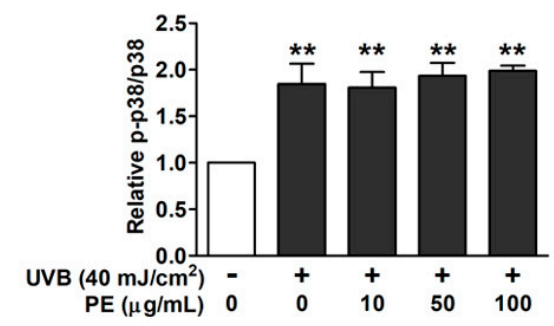

(c)

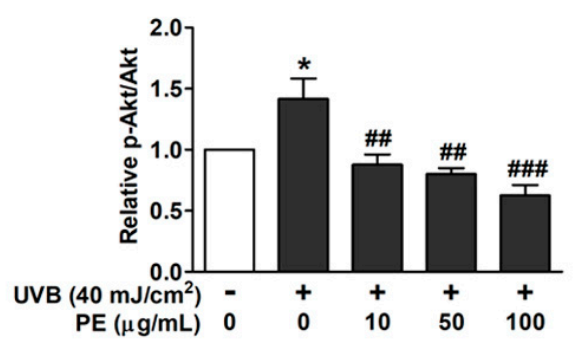

(b)

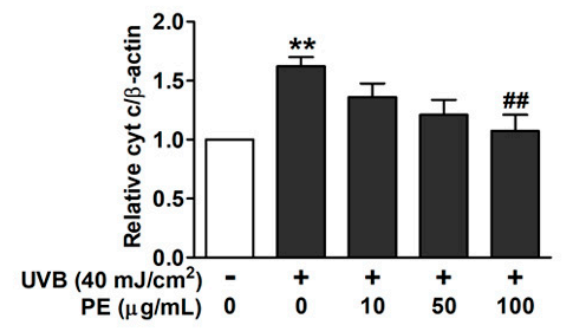

(d)

Figure 6. The effects of PE on the UVB-induced activation of p-Akt, p-p38, and cyt c in HaCaT cells. (a) The protein bands for p-Akt, Akt, p-p38, p38, cyt c, and $\beta$-actin. The relative ratios of (b) p-Akt/Akt, (c) p-p38/p38, and (d) cyt c/ $\beta$-actin. The data are shown as the mean \pm SEM $(n=3)$. ${ }^{*}, p<0.05$, and ${ }^{* *} p<0.01$, when compared to the non-UVB group; ${ }^{\#}, p<0.01$, and ${ }^{\# \#}, p<0.001$, when compared to the UVB-exposed group.

Signaling through p38 was significantly increased by $1.85 \pm 0.22$-fold in UVB-exposed HaCaT cells; however, PE pretreatment did not alter the triggering of p38 phosphorylation (Figure 6c). The release of cyt $\mathrm{c}$ in UVB-irradiated HaCaT cells increased $1.77 \pm 0.12$-fold; however, PE at $100 \mu \mathrm{g} / \mathrm{mL}$ significantly mitigated this increase in apoptotic signal down to $1.07 \pm 0.14$-fold (Figure $6 \mathrm{~d}$ ).

\section{Discussion}

Repeated exposure to UVB radiation induces premature skin aging and skin cancer $[23,24]$. The skin epidermis, particularly the outermost layer, mainly consisting of keratinocytes, is the first layer exposed to these harmful UVB rays, leading to functional changes and cellular damage. The molecular mechanisms involved in UVB-induced keratinocyte injury include DNA damage, ROS production, inflammation, and apoptosis [25]. To prevent the development of skin cancer, avoiding excessive exposure to $\mathrm{UV}$ radiation or applying UV protective agents is essential. A natural PE extract has a keratoprotective effect mediated by antioxidative, anti-inflammatory, and anti-apoptotic activities in skin keratinocytes exposed to UVB irradiation. 
The antioxidant effects of PE are markedly contributed to ascorbic acid, phenolics, flavonoids, and tannoids [26-28]. PE aqueous fruit extracts are similar in their antioxidant contents to organic solvent extracts, such as methanolic extracts [29]. Ascorbic acid is the most abundant antioxidant constituent in PE; however, there is a challenge in maintaining the stability and improving delivery to target sites when it is used for skin cosmetics and pharmaceuticals.

Beyond their antioxidant effects, other valuable phytoantioxidants found in PE, such as chlorogenic acid, ellagic acid, gallic acid, and quercetin, could reduce skin inflammation originating from dermatitis or UV-induced oxidative damage [30-33]. Although phyllanthins are expected to be detected in plants belonging to the genus Phyllanthus, they were absent in the PE fruit juice extract.

Concordant with the study by Srirama et al. [34], of 11 Phyllanthus species, for both methanolic and aqueous extracts, only P. amarus Schumach contained phyllanthin and hypophyllantin; however, these two specific phytochemicals did not reflect the hepatoprotective properties of the plant extracts. Thus, the attenuation of ROS production and the keratinoprotective effect of PE against UVB irradiation are potentially derived from other phytoantioxidants, such as the ascorbic acid, flavonoids, and phenolics found in PE. This is supported by the study by Sowa et al. [35] demonstrating that the medicinal plant extracts consisting of high antioxidant and high phenolic contents promoted skin fibroblast proliferation and wound healing. Additionally, the plant extracts from the Carlina genus mainly containing triterpenes and phenolic acids selectively enhanced fibroblast proliferation but inhibited UACC-903 and UACC-647 melanoma cell growth [36].

The antioxidant properties of fruit and vegetables have been widely determined through FRAP and ORAC assays [37]. The FRAP value of our PE fresh fruit extract $(4.66 \pm 0.27 \mu \mathrm{mol} / \mathrm{mg})$ was lower than that of the PE dried fruit extract $(7.46 \pm 0.56 \mu \mathrm{mol} / \mathrm{mg})$ previously reported from a study by Charoenteeraboon et al. [38], due to the concentration of the nutrient and antioxidant compounds in the dried form [39].

The measured ORAC capacity of the PE fruit juice extract (5480 $\mu \mathrm{mol} \mathrm{TE} / \mathrm{g}$ ) was similar to the ORAC value of lemon polyphenol (5400 $\mu \mathrm{mol} \mathrm{TE} / \mathrm{g})$, which exhibits very high antioxidant activity and anti-aging properties [40]. To preserve healthy skin, lemon juice extract has been used in skincare products, such as masks and skin conditioners [41]. According to the equivalent capacity of PE and lemon, PE could have skin-protective capabilities and may be used as an ingredient in skin-protection products.

A marked elevation of intracellular ROS is one of the primary phenomena observed in keratinocyte responses to UVB irradiation [42]. The specific ROS that are initially generated during UV exposure include $\mathrm{H}_{2} \mathrm{O}_{2}$ and $\mathrm{O}_{2}{ }^{\bullet-}$, which induce overall cellular oxidative stress, leading to multiple cascades of signal transduction ultimately associated with cellular adaptations and apoptosis [43]. In vitro analysis revealed that PE juice extract was capable of scavenging important ROS generated during UV exposure, including $\mathrm{OH}^{\bullet}$, $\mathrm{O}_{2}^{\bullet-}$, and $\mathrm{H}_{2} \mathrm{O}_{2}$.

PE attenuated detrimental ROS formation and scavenged the most abundant ROS that occurred during UVB irradiation. Although GPx was not altered in this study, a noticeable elevation of SOD activity in response to UVB exposure was evident in keratinocytes both with and without PE preincubation. However, the intracellular $\mathrm{O}_{2}{ }^{\bullet-}$ levels were significantly reduced only in cells treated with PE. This indicates that the amount of $\mathrm{O}_{2}{ }^{\bullet-}$ generated during UVB activation overwhelmed the capacity of SOD to eliminate $\mathrm{O}_{2}^{\bullet-}$ and maintain it at basal levels without the assistance of PE's ROS-scavenging activity.

Keratinocytes are more vulnerable to oxidative stress than skin fibroblasts because they are lower in first-line antioxidant enzyme activities, i.e., those of SOD, CAT, and GPx [44]. Only keratinocytes overexpressing CAT showed a marked reduction in UVB-induced apoptosis; however, this protective effect was not observed in keratinocytes with SOD overexpression [45]. This suggests that $\mathrm{H}_{2} \mathrm{O}_{2}$ plays a critical role in keratinocyte apoptosis as induced by UVB. In this study, the highly active SOD induced by UVB generated great amounts of $\mathrm{H}_{2} \mathrm{O}_{2}$, which, in turn, could be removed by the action of PE through the 
activation of the presumably peroxidative (rather than catalytic) CAT activity, which is necessary for reducing high levels of $\mathrm{H}_{2} \mathrm{O}_{2}$ [46].

The activity of $\mathrm{PE}$ in scavenging $\mathrm{H}_{2} \mathrm{O}_{2}$ is a combination of the attenuation of intracellular $\mathrm{H}_{2} \mathrm{O}_{2}$ levels and a significant increase in CAT activity in keratinocytes treated with $P E$. PE reduced the total intracellular ROS, which partly corresponded to the decreased level of $\mathrm{H}_{2} \mathrm{O}_{2}$ as well as the enhanced CAT activity. The control of endogenous $\mathrm{H}_{2} \mathrm{O}_{2}$ is crucial, as, in aged human skin and vitiligo conditions, the accumulation of $\mathrm{H}_{2} \mathrm{O}_{2}$ along with a reduction in CAT activity has been observed [47,48].

Thus, the maintenance of the appropriate levels and harmonizing the functions of these antioxidant enzymes, rather than focusing on single enzymes, is important in balancing the cellular redox status, which works synergistically to maintain the overall defense mechanisms for cytoprotection. In high-oxidative-stress conditions, such as Down's syndrome (DS), increased activities of SOD and GPx and reduced activity of CAT in erythrocytes are evident [49]. This imbalance may lead to detrimental effects on neuronal cells, hence impairing cognitive function in DS.

Inflammation and apoptosis are two closely related events observed in keratinocytes exposed to UVB irradiation [50]. UV irradiation induces inflammatory signaling responses through the activation of transcription factors, including AP-1 (c-Fos/c-Jun), NF- $\mathrm{kB}$, NFATs, and STATs, which, in turn, promote the production of inflammatory cytokines and prostanoids [51]. The AP-1 family protein c-Jun and the transcription factor NF- $\mathrm{kB}$ are the predominant UV-response genes that play important roles in the inflammatory process and the development of skin cancer [52]. PE blocked UVB-induced inflammation in $\mathrm{HaCaT}$ cells by suppressing AP-1 and the NF- $\mathrm{kB}-\mathrm{COX}-2-\mathrm{PGE}_{2}$ axis.

Similar reports have shown that lutein, a natural carotenoid, reduced several proinflammatory mediators in the skin, including IL-6, TNF- $\alpha$, COX-2, and matrix-metallopeptidase- 9 (MMP-9) by decreasing the AP-1 signaling in UV-irradiated keratinocytes [53]. It is conceivable that quercetin, a component found in $\mathrm{PE}$, may inhibit UV-induced cytokine production in $\mathrm{HaCaT}$ cells by suppressing the NF- $\mathrm{KB}$ pathway as well as inactivating the AP-1 pathway [50]. Altogether, PE inhibited key components of the inflammatory responses in $\mathrm{HaCaT}$ cells exposed to UVB. It is postulated that the main antioxidant components of PE such as ascorbic acid [54,55], ellagic acid [56], gallic acid [57], chlorogenic acid [32], quercetin [58], and others, are accountable for reducing proinflammatory cytokine/chemokine releases (e.g., TNF $\alpha$, IL-8, $\mathrm{MCP}-1$ ), inhibiting signal transduction toward inflammation process (e.g., COX-2 expression and NF- $\mathrm{KB}$ activation), and protection against UVB-induced apoptosis.

UVB rays induce DNA damage, cell cycle arrest, and apoptosis [59]. The process of programmed cell death is typically characterized by physiological and morphological changes that depend on the stage of apoptosis. During the early stages, several events occur, including the shift of phosphatidylserine from the inner cell to the outer cell surface, the depolarization of the mitochondrial membrane potential, cell shrinkage, and chromatin condensation. In the late stages of apoptosis, the cells lose membrane integrity and fragment into apoptotic bodies [60].

$\mathrm{UVB}$, at the dose and time of detection used in this experiment, induced late apoptosis (Hoechst staining) but not necrosis (PI staining). The intrinsic pathways that induce apoptosis were derived from the overproduction of ROS, leading to mitochondrial cyt c release, which could be inhibited by the scavenging of intracellular ROS [61]. The antioxidant property of PE inhibited the UVB-induced ROS production and reduced cyt $c$ release, which could ultimately inhibit the triggering of downstream apoptotic executor proteins, such as caspase- 9 and caspase- -3 .

The molecular mechanisms of UVB-induced apoptosis also involve the tumor suppressor protein $\mathrm{p} 53$, which has been found to be mutated in HaCaT cells and most skin tumor cells. Blocking the mutated p53 proteins could partially block UVB-induced apoptosis in $\mathrm{HaCaT}$ cells [62]. Hence, other signaling pathways influence the homeostasis between cell survival and the induction of apoptosis in HaCaT cells. 
The MAPK signaling pathways, such as Akt, JNK, ERK, and p38, also play a pivotal role in the responses to UVB-induced ROS generation, leading to AP-1- and NF-KBmediateed inflammatory processes in the skin [63], which could be deactivated by PE. The inhibition of the UV-induced activation of the Akt pathway by PE could be the mediator of the anti-inflammatory effects induced by the downstream modulation of AP-1 and NF- $\mathrm{kB}$ signals, as there was no alteration in $\mathrm{p} 38$ phosphorylation in the PE-treated keratinocytes exposed to UVB.

Although a preventive role of PE on p38-induced apoptosis was excluded, p38 promoted the translocation of Bax from the cytosol to the mitochondria, causing cyt $\mathrm{c}$ release and caspase activation [64], maintaining that Akt signaling is crucial for cellular homeostasis and cellular adaptation promoting $\mathrm{HaCaT}$ cell survival and inhibiting UVB-induced cell death. Regarding this, the mechanisms of PE in protecting HaCaT cells from UVB-induced oxidative stress, inflammation, and apoptosis are summarized and demonstrated in Figure 7.

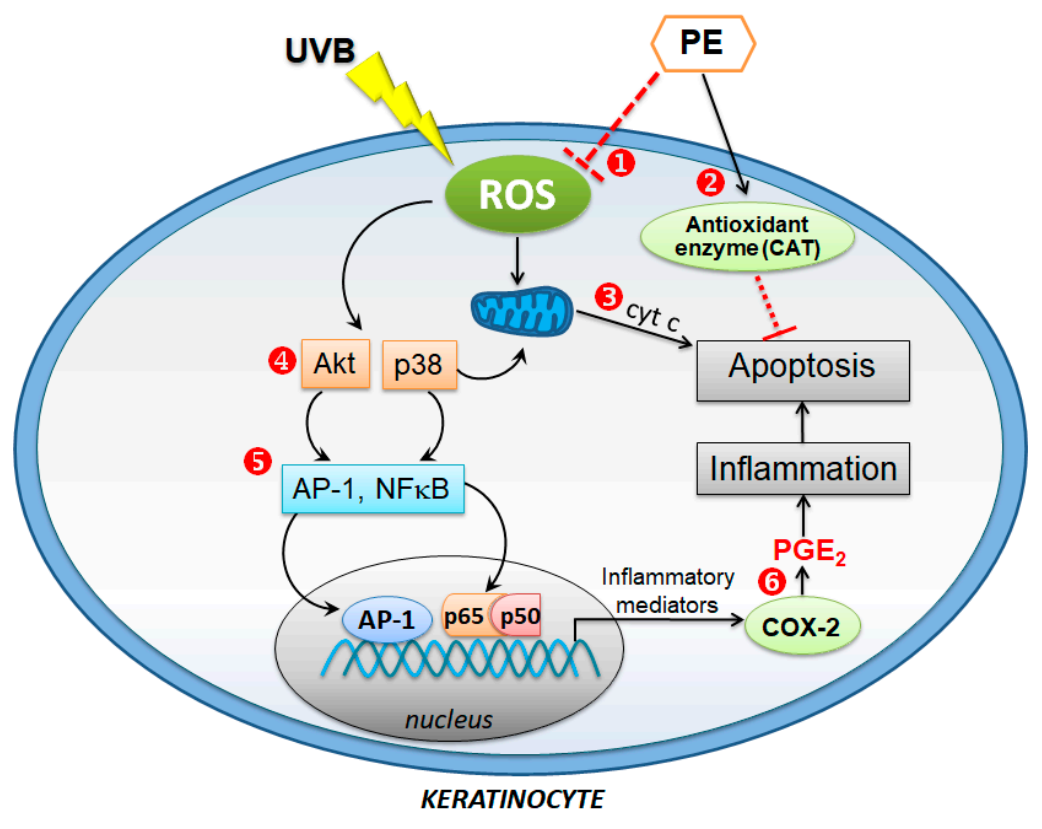

Figure 7. Schematic diagram depicting the proposed mechanisms of PE cytoprotection against UVB-induced HaCaT cell inflammation and apoptosis. (1) The antioxidant effects of PE predominantly reduced ROS generation, particularly hydrogen peroxide generation, and (2) the endogenous antioxidant defense enzyme CAT was activated. 3 PE inhibited cyt c release. While PE had no impact on p38-induced apoptosis, it inhibited the dysregulation of PI3K/Akt 4, which partakes in the balance of signaling pathways toward cell survival or apoptosis. PE attenuated the inflammatory response to UVB irradiation via the inhibition of the inflammatory signaling of $5 \mathrm{AP}-1, \mathrm{NF}-\mathrm{kB}$, and the mediator $6 \mathrm{PGE}_{2}$.

\section{Conclusions}

PE protected HaCaT cells from UVB-induced oxidative stress and apoptosis by eliminating excessive ROS, activating the antioxidant enzyme CAT, reducing cyt c release, inhibiting Akt overactivity, and mitigating the inflammatory signals AP-1 and NF- $\mathrm{KB}$ and the inflammatory mediator $\mathrm{PGE}_{2}$. The results support the use of $\mathrm{PE}$ as an active ingredient for skin protection from UV irradiation.

Supplementary Materials: The following are available online at https:/ / www.mdpi.com/article/10.3 390/antiox10050703/s1, Figure S1: High-performance liquid chromatography (HPLC) chromatograms, standard calibration curve and DAD spectra for six phytoantioxidants in Phyllanthus emblica L. fruit extract (PE), including (a) ascorbic acid, (c) chlorogenic acid, (e) ellagic acid, (g) gallic acid, (i) phyllathin, and $(\mathrm{k})$ quercetin. The chromatograms of the standard phyto-antioxidants are presented in the left column, while the contents in the PE sample are indicated in the right column, compared with the 
corresponding standards. Figure S2: The effects of UVB and PE on the HaCaT cell viability. (a) The relative cell viability of HaCaT cells after irradiation with various doses of UVB. (b) The effects of PE pretreatment followed by UVB irradiation. Figure S3: Original images of western blot band intensities in Figure 4. Figure S4: Original images of western blot band intensities in Figure 5. Figure S5: Original images of western blot band intensities in Figure 6.

Author Contributions: Conceptualization, S.K.W.; methodology, validation, and formal analysis, K.K., S.K.W. and L.C.; investigation and data curation, K.K. and W.J.; writing-original draft preparation, K.K.; writing-review and editing, S.K.W.; visualization and supervision, S.K.W.; project administration, S.K.W.; funding acquisition, S.K.W. and L.C. All authors have read and agreed to the published version of the manuscript.

Funding: This research was funded by The Royal Golden Jubilee Ph.D. Program, grant numbers PHD57K0036 and PHD58K0048; Srinakharinwirot University research grants (grant numbers 248/2559 and 212/2560); and a Thammasat University research grant (2560).

Institutional Review Board Statement: Not applicable.

Informed Consent Statement: Not applicable.

Data Availability Statement: The data are contained within the article.

Acknowledgments: The BIO-SUN UV irradiation system was provided by the Equipment Subsidies Program, Alexander von Humboldt Foundation.

Conflicts of Interest: The authors declare no conflict of interest.

\section{References}

1. Armstrong, B.K.; Cust, A.E. Sun exposure and skin cancer, and the puzzle of cutaneous melanoma: A perspective on Fears et al. Mathematical models of age and ultraviolet effects on the incidence of skin cancer among whites in the United States. American Journal of Epidemiology 1977; 105: 420-427. Cancer Epidemiol. 2017, 48, 147-156. [CrossRef] [PubMed]

2. Wölfle, U.; Seelinger, G.; Bauer, G.; Meinke, M.C.; Lademann, J.; Schempp, C.M. Reactive molecule species and antioxidative mechanisms in normal skin and skin aging. Skin Pharmacol. Physiol. 2014, 27, 316-332. [CrossRef] [PubMed]

3. De Vries, E.; Arnold, M.; Altsitsiadis, E.; Trakatelli, M.; Hinrichs, B.; Stockfleth, E.; Coebergh, J.; Group, E. Potential impact of interventions resulting in reduced exposure to ultraviolet (UV) radiation (UVA and UVB) on skin cancer incidence in four European countries, 2010-2050. Br. J. Dermatol. 2012, 167 (Suppl. 2), 53-62. [CrossRef]

4. Hegedus, C.; Boros, G.; Fidrus, E.; Kis, G.N.; Antal, M.; Juhasz, T.; Janka, E.A.; Janko, L.; Paragh, G.; Emri, G.; et al. PARP1 inhibition augments UVB-mediated mitochondrial changes-implications for UV-induced DNA repair and photocarcinogenesis. Cancers 2019, 12, 5. [CrossRef] [PubMed]

5. Johann To Berens, P.; Molinier, J. Formation and recognition of UV-induced DNA damage within genome complexity. Int. J. Mol. Sci. 2020, 21, 6689. [CrossRef] [PubMed]

6. Gu, Y.; Han, J.; Jiang, C.; Zhang, Y. Biomarkers, oxidative stress and autophagy in skin aging. Ageing Res. Rev. 2020, 59, 101036. [CrossRef] [PubMed]

7. Moan, J.; Grigalavicius, M.; Baturaite, Z.; Dahlback, A.; Juzeniene, A. The relationship between UV exposure and incidence of skin cancer. Photodermatol. Photoimmunol. Photomed. 2015, 31, 26-35. [CrossRef] [PubMed]

8. D'Ignazio, L.; Batie, M.; Rocha, S. Hypoxia and inflammation in cancer, focus on HIF and NF-kappaB. Biomedicines 2017, 5, 21. [CrossRef] [PubMed]

9. Anwar, A.; Anwar, H.; Yamauchi, T.; Tseng, R.; Agarwal, R.; Horwitz, L.D.; Zhai, Z.; Fujita, M. Bucillamine inhibits UVB-induced MAPK activation and apoptosis in human HaCaT keratinocytes and SKH-1 hairless mouse skin. Photochem. Photobiol. 2020, 96, 870-876. [CrossRef] [PubMed]

10. Chamcheu, J.C.; Esnault, S.; Adhami, V.M.; Noll, A.L.; Banang-Mbeumi, S.; Roy, T.; Singh, S.S.; Huang, S.; Kousoulas, K.G.; Mukhtar, H. Fisetin, a 3,7, $3^{\prime}, 4^{\prime}$-Tetrahydroxyflavone inhibits the PI3K/Akt/mTOR and MAPK pathways and ameliorates psoriasis pathology in 2D and 3D organotypic human inflammatory skin models. Cells 2019, 8, 1089. [CrossRef]

11. Ahmed, I.A.; Mikail, M.A.; Zamakshshari, N.; Abdullah, A.H. Natural anti-aging skincare: Role and potential. Biogerontology 2020, 21, 293-310. [CrossRef]

12. Ngoc, L.T.N.; Tran, V.V.; Moon, J.-Y.; Chae, M.; Park, D.; Lee, Y.-C. Recent trends of sunscreen cosmetic: An update review. Cosmetics 2019, 6, 64. [CrossRef]

13. Gantait, S.; Mahanta, M.; Bera, S.; Verma, S.K. Advances in biotechnology of Emblica officinalis Gaertn. syn. Phyllanthus emblica L.: A nutraceuticals-rich fruit tree with multifaceted ethnomedicinal uses. 3 Biotech 2021, 11, 62. [CrossRef]

14. Variya, B.C.; Bakrania, A.K.; Patel, S.S. Emblica officinalis (Amla): A review for its phytochemistry, ethnomedicinal uses and medicinal potentials with respect to molecular mechanisms. Pharmacol. Res. 2016, 111, 180-200. [CrossRef] 
15. Boukamp, P.; Petrussevska, R.T.; Breitkreutz, D.; Hornung, J.; Markham, A.; Fusenig, N.E. Normal keratinization in a spontaneously immortalized aneuploid human keratinocyte cell line. J. Cell Biol. 1988, 106, 761-771. [CrossRef]

16. Chularojmontri, L.; Suwatronnakorn, M.; Wattanapitayakul, S.K. Phyllanthus emblica L. Enhances human umbilical vein endothelial wound healing and sprouting. Evid. Based Complement. Altern. Med. 2013, 2013, 720728. [CrossRef]

17. Sawant, L.; Prabhakar, B.; Nancy, P. Quantitative HPLC analysis of ascorbic acid and gallic acid in Phyllanthus Emblica. J. Anal. Bioanal. Tech. 2010, 1, 1-4. [CrossRef]

18. Sawant, L.; Prabhakar, B.; Mahajan, A.; Pai, N.; Pandita, N. Development and validation of HPLC method for quantification of phytoconstituents in Phyllanthus emblica. J. Chem. Pharm. Res. 2011, 3, 937-944.

19. Jarisarapurin, W.; Sanrattana, W.; Chularojmontri, L.; Kunchana, K.; Wattanapitayakul, S.K. Antioxidant properties of unripe Carica papaya fruit extract and its protective effects against endothelial oxidative stress. Evid. Based Complement. Altern. Med. 2019, 2019, 4912631. [CrossRef]

20. Chen, J.; Rogers, S.C.; Kavdia, M. Analysis of kinetics of dihydroethidium fluorescence with superoxide using xanthine oxidase and hypoxanthine assay. Ann. Biomed. Eng. 2013, 41, 327-337. [CrossRef]

21. Wheeler, C.R.; Salzman, J.A.; Elsayed, N.M.; Omaye, S.T.; Korte, D.W., Jr. Automated assays for superoxide dismutase, catalase, glutathione peroxidase, and glutathione reductase activity. Anal. Biochem. 1990, 184, 193-199. [CrossRef]

22. Schneider, C.A.; Rasband, W.S.; Eliceiri, K.W. NIH Image to ImageJ: 25 years of image analysis. Nat. Methods 2012, 9, 671-675. [CrossRef]

23. Bagde, A.; Mondal, A.; Singh, M. Drug delivery strategies for chemoprevention of UVB-induced skin cancer: A review. Photodermatol. Photoimmunol. Photomed. 2018, 34, 60-68. [CrossRef]

24. Silveira, J.E.P.S.; Pedroso, D.M.M. UV light and skin aging. Rev. Environ. Health 2014, 29, 243-254. [CrossRef]

25. D'Orazio, J.; Jarrett, S.; Amaro-Ortiz, A.; Scott, T. UV radiation and the skin. Int. J. Mol. Sci. 2013, 14, 12222-12248. [CrossRef] [PubMed]

26. Bhattacharya, A.; Chatterjee, A.; Ghosal, S.; Bhattacharya, S.K. Antioxidant activity of active tannoid principles of Emblica officinalis (amla). Indian J. Exp. Biol. 1999, 37, 676-680. [PubMed]

27. Liu, X.; Cui, C.; Zhao, M.; Wang, J.; Luo, W.; Yang, B.; Jiang, Y. Identification of phenolics in the fruit of emblica (Phyllanthus emblica L.) and their antioxidant activities. Food Chem. 2008, 109, 909-915. [CrossRef] [PubMed]

28. Pientaweeratch, S.; Panapisal, V.; Tansirikongkol, A. Antioxidant, anti-collagenase and anti-elastase activities of Phyllanthus emblica, Manilkara zapota and silymarin: An in vitro comparative study for anti-aging applications. Pharm. Biol. 2016, 54, 1865-1872. [CrossRef] [PubMed]

29. Li, W.; Zhang, X.; Chen, R.; Li, Y.; Miao, J.; Liu, G.; Lan, Y.; Chen, Y.; Cao, Y. HPLC fingerprint analysis of Phyllanthus emblica ethanol extract and their antioxidant and anti-inflammatory properties. J. Ethnopharmacol. 2020, 254, 112740. [CrossRef] [PubMed]

30. Tsang, M.S.; Jiao, D.; Chan, B.C.; Hon, K.L.; Leung, P.C.; Lau, C.B.; Wong, E.C.; Cheng, L.; Chan, C.K.; Lam, C.W.; et al. Anti-inflammatory activities of pentaherbs formula, berberine, gallic acid and chlorogenic acid in atopic dermatitis-like skin inflammation. Molecules 2016, 21, 519. [CrossRef] [PubMed]

31. Yin, Y.; Li, W.; Son, Y.O.; Sun, L.; Lu, J.; Kim, D.; Wang, X.; Yao, H.; Wang, L.; Pratheeshkumar, P.; et al. Quercitrin protects skin from UVB-induced oxidative damage. Toxicol. Appl. Pharmacol. 2013, 269, 89-99. [CrossRef]

32. Cha, J.W.; Piao, M.J.; Kim, K.C.; Yao, C.W.; Zheng, J.; Kim, S.M.; Hyun, C.L.; Ahn, Y.S.; Hyun, J.W. The polyphenol chlorogenic acid attenuates UVB-mediated oxidative stress in human HaCaT keratinocytes. Biomol. Ther. 2014, 22, 136-142. [CrossRef]

33. Xu, D.; Hu, M.J.; Wang, Y.Q.; Cui, Y.L. Antioxidant activities of quercetin and its complexes for medicinal application. Molecules 2019, 24, 1123. [CrossRef]

34. Srirama, R.; Deepak, H.B.; Senthilkumar, U.; Ravikanth, G.; Gurumurthy, B.R.; Shivanna, M.B.; Chandrasekaran, C.V.; Agarwal, A.; Shaanker, R.U. Hepatoprotective activity of Indian Phyllanthus. Pharm. Biol. 2012, 50, 948-953. [CrossRef]

35. Sowa, I.; Paduch, R.; Strzemski, M.; Zielinska, S.; Rydzik-Strzemska, E.; Sawicki, J.; Kocjan, R.; Polkowski, J.; Matkowski, A.; Latalski, M.; et al. Proliferative and antioxidant activity of Symphytum officinale root extract. Nat. Prod. Res. 2018, 32, 605-609. [CrossRef]

36. Strzemski, M.; Wojnicki, K.; Sowa, I.; Wojas-Krawczyk, K.; Krawczyk, P.; Kocjan, R.; Such, J.; Latalski, M.; Wnorowski, A.; Wojciak-Kosior, M. In Vitro Antiproliferative Activity of Extracts of Carlina acaulis subsp. caulescens and Carlina acanthifolia subsp. utzka. Front. Pharmacol. 2017, 8, 371. [CrossRef]

37. Thaipong, K.; Boonprakob, U.; Crosby, K.; Cisneros-Zevallos, L.; Hawkins Byrne, D. Comparison of ABTS, DPPH, FRAP, and ORAC assays for estimating antioxidant activity from guava fruit extracts. J. Food Compost. Anal. 2006, 19, 669-675. [CrossRef]

38. Charoenteeraboon, J.; Wongnoppavich, A.; Soonthornchareonnon, N.; Jaijoy, K.; Sireeratawong, S. Antioxidant activities of the standardized water extract from fruit of Phyllanthus emblica Linn. Songklanakarin J. Sci. Technol. 2010, 32, 599-604.

39. Vinson, J.A.; Zubik, L.; Bose, P.; Samman, N.; Proch, J. Dried fruits: Excellent in vitro and in vivo antioxidants. J. Am. Coll. Nutr. 2005, 24, 44-50. [CrossRef]

40. Shimizu, C.; Wakita, Y.; Inoue, T.; Hiramitsu, M.; Okada, M.; Mitani, Y.; Segawa, S.; Tsuchiya, Y.; Nabeshima, T. Effects of lifelong intake of lemon polyphenols on aging and intestinal microbiome in the senescence-accelerated mouse prone 1 (SAMP1). Sci. Rep. 2019, 9, 3671. [CrossRef] 
41. Klimek-Szczykutowicz, M.; Szopa, A.; Ekiert, H. Citrus limon (lemon) phenomenon-a review of the chemistry, pharmacological properties, applications in the modern pharmaceutical, food, and cosmetics industries, and biotechnological studies. Plants 2020, 9, 119. [CrossRef]

42. Atalay, S.; Dobrzyńska, I.; Geggotek, A.; Skrzydlewska, E. Cannabidiol protects keratinocyte cell membranes following exposure to UVB and hydrogen peroxide. Redox Biol. 2020, 36, 101613. [CrossRef]

43. Dhumrongvaraporn, A.; Chanvorachote, P. Kinetics of ultraviolet B irradiation-mediated reactive oxygen species generation in human keratinocytes. J. Cosmet. Sci. 2013, 64, 207-217.

44. Yohn, J.J.; Norris, D.A.; Yrastorza, D.G.; Buno, I.J.; Leff, J.A.; Hake, S.S.; Repine, J.E. Disparate antioxidant enzyme activities in cultured human cutaneous fibroblasts, keratinocytes, and melanocytes. J. Investig. Dermatol. 1991, 97, 405-409. [CrossRef]

45. Rezvani, H.R.; Mazurier, F.; Cario-Andre, M.; Pain, C.; Ged, C.; Taieb, A.; de Verneuil, H. Protective effects of catalase overexpression on UVB-induced apoptosis in normal human keratinocytes. J. Biol. Chem. 2006, 281, 17999-18007. [CrossRef]

46. Nicell, J.A.; Wright, H. A model of peroxidase activity with inhibition by hydrogen peroxide. Enzym. Microb. Technol. 1997, 21, 302-310. [CrossRef]

47. Shin, M.H.; Rhie, G.E.; Kim, Y.K.; Park, C.H.; Cho, K.H.; Kim, K.H.; Eun, H.C.; Chung, J.H. $\mathrm{H}_{2} \mathrm{O}_{2}$ accumulation by catalase reduction changes MAP kinase signaling in aged human skin in vivo. J. Investig. Dermatol. 2005, 125, 221-229. [CrossRef]

48. Schallreuter, K.U.; Moore, J.; Wood, J.M.; Beazley, W.D.; Gaze, D.C.; Tobin, D.J.; Marshall, H.S.; Panske, A.; Panzig, E.; Hibberts, N.A. In vivo and in vitro evidence for hydrogen peroxide $\left(\mathrm{H}_{2} \mathrm{O}_{2}\right)$ accumulation in the epidermis of patients with vitiligo and its successful removal by a UVB-activated pseudocatalase. J. Investig. Dermatol. Symp. Proc. 1999, 4, 91-96. [CrossRef]

49. Garaiová, I.; Muchová, J.; Šustrová, M.; Blažíček, P.; Sivoňová, M.; Kvasnička, P.; Siegfried, P.; Ďuračková, Z. The relationship between antioxidant systems and some markers of oxidative stress in persons with Down syndrome. Biol. Bratisl. 2004, 59, 787-794.

50. Hatakeyama, M.; Fukunaga, A.; Washio, K.; Taguchi, K.; Oda, Y.; Ogura, K.; Nishigori, C. Anti-inflammatory role of langerhans cells and apoptotic keratinocytes in ultraviolet-B-induced cutaneous inflammation. J. Immunol. 2017, 199, 2937-2947. [CrossRef]

51. Uluckan, O.; Guinea-Viniegra, J.; Jimenez, M.; Wagner, E.F. Signalling in inflammatory skin disease by AP-1 (Fos/Jun). Clin. Exp . Rheumatol. 2015, 33, S44-S49. [PubMed]

52. Cooper, S.J.; Bowden, G.T. Ultraviolet B regulation of transcription factor families: Roles of nuclear factor-kappa B (NF-kappaB) and activator protein-1 (AP-1) in UVB-induced skin carcinogenesis. Curr. Cancer Drug Targets 2007, 7, 325-334. [CrossRef] [PubMed]

53. Vicentini, F.T.; He, T.; Shao, Y.; Fonseca, M.J.; Verri, W.A., Jr.; Fisher, G.J.; Xu, Y. Quercetin inhibits UV irradiation-induced inflammatory cytokine production in primary human keratinocytes by suppressing NF-kappaB pathway. J. Dermatol. Sci. 2011, 61, 162-168. [CrossRef] [PubMed]

54. Kang, J.S.; Kim, H.N.; Jung, D.J.; Kim, J.E.; Mun, G.H.; Kim, Y.S.; Cho, D.; Shin, D.H.; Hwang, Y.I.; Lee, W.J. Regulation of UVB-induced IL-8 and MCP-1 production in skin keratinocytes by increasing vitamin C uptake via the redistribution of SVCT-1 from the cytosol to the membrane. J. Investig. Dermatol. 2007, 127, 698-706. [CrossRef]

55. Kawashima, S.; Funakoshi, T.; Sato, Y.; Saito, N.; Ohsawa, H.; Kurita, K.; Nagata, K.; Yoshida, M.; Ishigami, A. Protective effect of pre- and post-vitamin C treatments on UVB-irradiation-induced skin damage. Sci. Rep. 2018, 8, 16199. [CrossRef]

56. Lembo, S.; Balato, A.; Di Caprio, R.; Cirillo, T.; Giannini, V.; Gasparri, F.; Monfrecola, G. The modulatory effect of ellagic acid and rosmarinic acid on ultraviolet-B-induced cytokine/chemokine gene expression in skin keratinocyte (HaCaT) cells. Biomed. Res. Int. 2014, 2014, 346793. [CrossRef]

57. Kahkeshani, N.; Farzaei, F.; Fotouhi, M.; Alavi, S.S.; Bahramsoltani, R.; Naseri, R.; Momtaz, S.; Abbasabadi, Z.; Rahimi, R.; Farzaei, M.H.; et al. Pharmacological effects of gallic acid in health and diseases: A mechanistic review. Iran J. Basic Med. Sci. 2019, 22, 225-237. [CrossRef]

58. Zhu, X.; Li, N.; Wang, Y.; Ding, L.; Chen, H.; Yu, Y.; Shi, X. Protective effects of quercetin on UVB irradiation-induced cytotoxicity through ROS clearance in keratinocyte cells. Oncol. Rep. 2017, 37, 209-218. [CrossRef]

59. Chen, A.; Huang, X.; Xue, Z.; Cao, D.; Huang, K.; Chen, J.; Pan, Y.; Gao, Y. The role of p21 in apoptosis, proliferation, cell cycle arrest, and antioxidant activity in UVB-irradiated human HaCaT keratinocytes. Med. Sci. Monit. Basic Res. 2015, $21,86-95$. [CrossRef]

60. D'Arcy, M.S. Cell death: A review of the major forms of apoptosis, necrosis and autophagy. Cell Biol. Int. 2019, 43, 582-592. [CrossRef]

61. Assefa, Z.; Garmyn, M.; Vantieghem, A.; Declercq, W.; Vandenabeele, P.; Vandenheede, J.R.; Agostinis, P. Ultraviolet B radiationinduced apoptosis in human keratinocytes: Cytosolic activation of procaspase-8 and the role of Bcl-2. FEBS Lett. 2003, 540, 125-132. [CrossRef]

62. Henseleit, U.; Zhang, J.; Wanner, R.; Haase, I.; Kolde, G.; Rosenbach, T. Role of p53 in UVB-induced apoptosis in human HaCaT keratinocytes. J. Investig. Dermatol. 1997, 109, 722-727. [CrossRef]

63. Altobelli, G.G.; Van Noorden, S.; Balato, A.; Cimini, V. Copper/Zinc Superoxide dismutase in human skin: Current knowledge. Front. Med. 2020, 7, 183. [CrossRef]

64. Van Laethem, A.; Van Kelst, S.; Lippens, S.; Declercq, W.; Vandenabeele, P.; Janssens, S.; Vandenheede, J.R.; Garmyn, M.; Agostinis, P. Activation of p38 MAPK is required for Bax translocation to mitochondria, cytochrome c release and apoptosis induced by UVB irradiation in human keratinocytes. FASEB J. 2004, 18, 1946-1948. [CrossRef] 